\title{
Stimulation of Bankim Chandra Chatterjee \& Rabindranath Tagore in Establishing Historical Research Institutions in Bengal: A Case Study of Varendra Research Society
}

\author{
Dinesh Chandra Ray ${ }^{1}$ \\ ${ }^{I}$ (Dept of History, Southfield College (Loreto College), Darjeeling, India)
}

\begin{abstract}
Historical researches had come into view in Bengal as well as India with the foundation of British rule, particularly, after the establishment of Asiatic society. Some British individuals like Wilkins, Buchanan and Cunningham too had involved themselves in this regard. Yet, due to paucity of time, none of them succeeded, either to make an uninterrupted exploration extensively, or to reconstruct the accurate history of Bengal, particularly of Ancient Bengal. Moreover the British scholars, from their biased and motivated outlook had painted bleak images of Indian rulers. On the other hand, at that time, the Bengalees were quite unaware of it. Actually, there was absence of an ambiance of historical cultural in the truest sense. Additionally there was the deficiency of written history, particularly of ancient period of Bengal. Consequently, the task of inculcating the ancient history of Bengal was much complicated one. Due to all these, thinkers like Bankim Chandra Chatterjee and Rabindranath Tagore even during the eighties of the nineteenth century had to lament and crave for the history of Bengal vis-à-vis Bengalees. Their grievances and appeal, however, finally had stirred the intellectuals of Rajsahi, like Akshaya Kumar Maitra, Sarat Kumar Ray and Ramaprasad Chanda who set up a research institution called Varendra Research Society to reconstruct the accurate history of Bengal.
\end{abstract}

Keywords-Aitihashik Chitra, Bankim Chandra Chatterjee \& Rabindranath Tagore, Gaudarajamala, Varendra.

Historical researches in Bengal, broadly speaking in scientific style, seem to have started with the establishment of British rule in India. The foremost initiatives were, however, taken up by the British scholars and it was gradually followed by the Indians. Sir William Jones may be regarded as one of the pioneer researchers in the discovery of India's past. Although Jones was not the earliest among the Orientalists, he seems to be the primary one to think in terms of foregrounding an enduring institution for Oriental studies and researches at a grand scale in this country. In 1784, he founded the Asiatic society "for enquiry into the history and antiquities, arts, science and literatures of Asia" (Journal of the Asiatic society of Bengal, 1832). This Asiatic Society had inspired in establishing a few other research societies and institutions, government and nongovernment, in various parts of India. The aims and objectives of all these societies and institutions were directed more or less, to explore and record the aspects of regional and local history and culture. The Varendra research Society (Varendra Anusandhan Samiti) was among one of these societies which was established in Rajshahi, now in Bangladesh, in the year 1910, primarily with the objective of "sequential investigation of evidences in Varendra [1] region". [2]

Keeping the influence and inspiration of the Asiatic Society of Bengal and the absence of written history [3], particularly of ancient period in view, it is to be mentioned that the establishment of a historical research society at Rajshahi, was the result of a different set of factors.

Among them, the influence of the grievances expressed by Bankim Chandra Chatterjee and Rabindranath Tagore in their writings related to history regarding the paucity of documentation was imperative one.

The foundation of the Varendra Research Society might have been directly or indirectly influenced by the historical contemplations and discontentment expressed by Bankim Chandra Chatterjee and Rabindranath Tagore. Actually the absence of an authentically documented scripted history of Bengal cum Bengalees even during the 80s of the nineteenth century had annoyed both Bankim Chandra Chatterjee and Rabindranath Tagore. Bengalees did not have a history - this misconstruction had turned into a maxim. [4] The lack of interest among the Bengalees regarding historical practices had augmented their frustration. For these reasons we can find that Bankim Chandra Chatterjee had not only pleaded for historical studies but also emphasized upon the importance of writing of history through his various essays like Muscle power of the Bengalees ('Bangaleer Bahubal'), The Disgrace of India ('Bharatkalanka'), A Few Words Regarding the History of Bengal ('Banglar Itihash Sammondhe koekti Katha'), The Disgrace of Bengal ('Banglar kalanka') and many others.

Out of his frustration from the unavailability of any written history of Bengal, Bankim Chandra Chatterjee had lamented that the history of Greenland has been written; even that of Maori people(people of 
Rajasthan) is on page; however, the land that was constituted of the places like Gour-Tamralipta-Saptagram etc, that land has no documented history in writing. According to him, the reason behind this is not scarcity of the components of writing history, but rather, the lack of any investigation.

In 1881, the editor of Bangadarshan had tried to inspire his readers by stating that it is the obligation of a race to write down its history. Instigating the people to fulfill this responsibility, Bankim Chandra has written:

There is no accessible history of Bengal, whatsoever is there is not history, rather fictions - only some narratives of the alien, invaders of Bengal and their biographies. We claim for the history of Bengal, else Bengal will be short of conviction. Who will write?

You will write, I will write, all of us will be writing it. Anyone who is a Bengalee needs to scribble it down. Even if the mother is dead, yet what delight in retelling her accounts? And since this Bengal, the land of our birth is our universal mother, and then is there no obvious enjoyment in chronicling about her? [5]

Rabindranath has called it an appetite for history. [6] After the death of Bankim Chandra Chatterjee in 1894, the cause was taken up by Rabindranath. Under his editorial, the Bengali journal entitled Sadhana started publishing essays related to the history of Bengal. In the preface to the first volume of Aitihashik Chitra, Tagore has written:

.....in memorizing entirely the history written by others, one might become an scholar or might score high marks in the examination, however, the impetus that is required in indigenous writing of history by collecting the native historical ingredients, that results not into eruditeness alone. That will create current in the stagnant pool of our mindscape. That instigation, that endeavor will enliven us. [7]

Regarding the commencement of the writing of the history of Bengalees by the Bengalee themselves, Tagore has written: "There is no harm in taking assistance from others so far as collection is concerned, but we should strengthen ourselves in the our resourcefulness."[8]

In reality, in response to Bankim's clarion call, the successful lawyer like Akshaya Kumar Maitra has taken up the nurturing of history through the collection of historical components, as his vocation. Saifuddin Chaudhury, a renowned historian of present Rajshahi has also assumed that Akshaya Kumar had realized the genuineness of Bankim Chandra's disappointment and thereby got motivated in his aspirations. [9] In this context, Saifuddin sahib has mentioned of Akshaya Kumar's play, Golam Husain. In Golam Husain Akshaya Kumar has himself written: "Due to the dearth of our indigenous history, we have become the object of ridicule by the foreigners... we don't write our history; don't show deserving respect to someone who is writing history; whether it is ancient or modern, we are equally indifferent to all. Presently in the newly awakened realm of Bengali literature, fictions are acclaimed more day by day. On the other hand, due to people's apathy, history of our land is getting dormant. Whatever is flourishing in the name of history is in majority, a mere derivation of the conclusions drawn by the foreign writers." $[10]$

The fact that Akshaya Kumar Maitra has got stimulated by Bankim Chandra Chatterjee, gets further support from the writing of Akshaya Kumar's follower, Rajendralal Acharya: "I do remember-we the school and college students had congregated together to condole on Bankim Chandra's demise....the entire hall was packed up. Akshaya Kumar's self-composed essay got read out in front of the multitudes by his own sweet voice. ...Intense reverence for Bankim Chandra got expressed in Akshaya Kumar's speech."[11]

However, Bankim Chandra Could not witnesses the activities of his devotee. Because, he expired (1894) few months before the publication of Akshaya Kumar's highly acclaimed book, Sirajaudullah. Aitihashik Chitra got published after a lapse of five years. Rabindranath happened to be Akshaya Kumar's friend. On account of Tagore's profound interest, Akshaya Kumar had started publishing his quarterly historical journal Aitihashik Chitra. [12]

Ramaprasad Chanda was so very influenced by reading Bankim Chandra's essays related to history that he could not stop himself from meeting Bankim Chandra. In that interaction with Bankim Chandra he had expressed of his preparation of writing an authentic history of Bengal. Having motivated him, Bankim Chandra recommended him to go for an effortful collection of evidences.22 Ramaprasad Chanda confessed of Bankim Chandra's influence upon him in his account entitled Bankim Chandra O Banglar Itihash:

“. - - having going through this touching episode, many Bengalee Youth aspiring to be poets had got inclined towards history. Having invited to play the leading role in the discourse of historical criticism, I feel honoured and whatever hard work I have undertaken, seems to be successful."'[13]

The cultural and majestic, Sarat Kumar Roy too was stimulated by the works of Bankim Chandra, which gets evident by his own statements:

“- - - how is it possible that the land with places like Gour, Tamralipta, Saptagram, does not poses a history? It is unfortunate that till date, no one could have apprehended the element of grievance that was implicit in this prophetic interrogation of Bankim Chandra."[14]

At this juncture, question might arise that, despite the fact that Bankim Chandra and Rabindranath had personally instigated Akshaya Kumar, Sarat Kumar and Ramaprasad, yet what relation does bear with the 
establishment a society? The answer to this question finds its germination in the following announcement of Bankim Chandra:

"Come let's work together for investigating the history of the Bengalees. Let them work as per their competence; a little fire flies illuminates far off places. This is not a task for single hand, together we must accomplish it."[15] The implication is that it is a universal work, a collective responsibility for it is to rescue the history of Bengal vis-à-vis Bengalees.

Bankim Chandra, Rabindranath Tagore followed by Akshaya Kumar, Sarat Kumar and Ramaprasad had all suffered from the distortion of history of India in general and Bengal in particular. The formers, by their pointed writing had tried to inspire the educated Bengalees to be historically engaged in preserving the history of Bengal from deformation. The later ones, motivated by the inspiration provided by the formers, organized themselves in gathering the ingredients of history of Bengal and nurture it scientifically for the sake of cleansing out the true and unmotivated history of Bengal.

The task of inculcating the ancient history of Bengal was much difficult one. Moreover the sequential explorations that was required to collect the resources for writing the ancient history of Bengal and also by comparing it with the other evidences related to Bengal's history, that were scattered all over India, was quite impossible a task for a single individual. As a solution, Varendra Research Society was set up as an institution that would symbolize collective endeavor. With the painstaking efforts of its members the Varendra Research Society was successful to carry out works of explorations adjacent to North Bengal and some other parts of Bengal, as well as few places of northern India. It also carried out works of excavations in some ancient sites of Bengal. Consequently, it has been able to assimilate he huge collection of splendid and unique relics of the past civilization of Bengal, that consisting of stone and copper plate inscriptions, sculptures, numismatic evidences, ancient documents and other antiquities of a miscellaneous nature. The relics represent successive phages of the bygone culture of the country extending from the pre Aryan times to the Mughal period. The library of the Varendra Research Society/ Varendra Research Museum has been able to secure 11075 volumes by October, 1964. These invaluable archaeological cum literary sources were indispensably required for any serious investigation, particularly the ones that were related to the political and cultural history of ancient Bengal. Henceforth, it can be affirmed that the creation of a repository of the ingredients prerequisite for scribbling down the history of Bengal, particularly that of the ancient times, is one of the major contributions made by Varendra Research Society. All of us, as Bengalees, should be indebted to Varendra Research Society for this.

Varendra Research Society, however, was not satiated in creating only a depository for the components of writing the history of Bengal. Within two years by its publication of Gaudarajamala and Gaudalekhamala has provided the required blow needed to change the conventional notion of history in Bengal. Its very release created profound commotion among the historical circuits. For, the society became beacon bearer who showed the path of writing the ancient history of Bengal on the basis of stone and copper inscriptions. It is to be noted that Gaudarajaramala and Gaudalekhamala has been considered as the path breaking work concerning the ancient history of Bengal, to have been ever written in scientific procedure.

\section{Books:}

\section{References}

\section{Reference no:}

[1] Chanda, Ramaprasad, Gaudarajamala, Varendra Research society, Rajsahi, 1912, see Upakramnika (Forward) by A. K. Maitra; see also Annual Report for the years 1925-16, 1926-27, 1935-36 \& 1949.

[2] Maitra, A. K., Uttarbangyer Puratatva Sangraha in Uttarbangyer Puratatva: Sankhipta Itihash, Akshaya Kumar Maitra Museum, University of North Bengal, 2005, p. 7

[3] Chatterjee, Bankim Chandra, Banglar Itihash Sammondhe Koekti Katha, in Bankim Rachnaballee, edited by Yogesh Chandra Bagol, Calcutta, Sahitya Samsad, Part-II, 1401 B.S., p.291.

[4] Chaudhury, Saifuddin \& Islam, Tasikul, Rajsahi Pratibha, Rajsahi Association, Rajsahi, 2000, p.18

[5] Ibid, see also Sahitya, $7^{\text {th }}$ year, No-1100, 1303 B.S., p.653

[6] Chanda, Ramaprasad, Itihashe Bangalee, K.P. Bagchi \& Company, Calcutta, 1981, Republished, 1997, p.46.

[7] Chatterjee, Bankim Chandra, Op.cit.

\section{Journals:}

[8] The region is now called Varendra -occupied form of the old name Varendri which lays on the north of the Ganges, in the colonial division of Rajsahi, between two rivers- the Mhananda on the West and the karotoya on the East.

[9] Ray, Sarat Kumar, Presidential Address, 1319 B.S.

[10] Aitihashik Chitra, Rabindra Rachanabali, part-V, p.599

[11] Tagore, Rabindranath, Introduction, Aitihashik Chitra, edited by A. K. Maitra, $1^{\text {st }}$ year, part -I, Rajsahi, 1899.

[12] Aitihashik Chitra op.cit, p.601.

[13] Bharatbarsha, 1344 B.S., Magha, P. 282

[14] Husain, Dilwar, Akshaya Kumar Maitra and Bangla Sahityndraa, in Journal Of the Varendra Research Museum, volume- VII, University of Rajsahi, 1985, p.16.

[15] Tagore, Rabindranath, op.cit. 